\title{
Receptions of Antiquity, Constructions of Gender in European Art, 1300-1600
}

\author{
Marice Rose \\ Fairfield University, mrose@fairfield.edu
}

Alison C. Poe

Follow this and additional works at: https://digitalcommons.fairfield.edu/visualandperformingarts-books Copyright 2015 Brill.

\section{Recommended Citation}

Rose, Marice and Poe, Alison C., "Receptions of Antiquity, Constructions of Gender in European Art, 1300-1600" (2015). Visual \& Performing Arts Faculty Book and Media Gallery. 19.

https://digitalcommons.fairfield.edu/visualandperformingarts-books/19

This item has been accepted for inclusion in DigitalCommons@Fairfield by an authorized administrator of DigitalCommons@Fairfield. It is brought to you by DigitalCommons@Fairfield with permission from the rightsholder(s) and is protected by copyright and/or related rights. You are free to use this item in any way that is permitted by the copyright and related rights legislation that applies to your use. For other uses, you need to obtain permission from the rights-holder(s) directly, unless additional rights are indicated by a Creative Commons license in the record and/or on the work itself. For more information, please contact digitalcommons@fairfield.edu. 


\title{
Introduction: Classical Reception, Gender Studies, and Art History
}

\author{
Marice Rose and Alison C. Poe
}

This volume employs classical reception, gender studies, and art history together to reconsider late medieval and early modern visual culture. The collected essays examine ways in which art in Italy, France, Germany, and elsewhere in Europe in the fourteenth to sixteenth century engaged both with Greek and Roman antiquity and with contemporary formulations of gender. The contributors address late medieval and Renaissance works of art that incorporate classical subject matter; drawings and engravings of ancient sculpture; displays of antiquities by collectors; written responses to ancient remains and textual imagery; and acts of viewing classical and classically informed art. These receptions of antiquity, the authors demonstrate, served in part to construct, normalize, complicate, and/or challenge late medieval and early modern conceptions of women, men, and those of intersexual status.

\section{Theoretical Framework}

The essays in this book posit a very wide range of responses to ancient physical and written remains among artists, patrons, and viewers from 1300 to 1600, and they look closely at the notions, intentions, and societal mechanisms that underpin those responses. The volume thus follows the definition by Lorna Hardwick of classical reception as "the artistic or intellectual processes involved in selecting, imitating or adapting ancient works," but it also treats display and viewing as active processes. ${ }^{1}$ The contributors make use of scholarship on the classical

\footnotetext{
${ }^{1}$ Lorna Hardwick, Reception Studies, Greece and Rome New Surveys in the Classics 33 (Oxford: Oxford University Press, 2003), 5.
} 
tradition in the late Middle Ages and Renaissance - especially studies that establish when, where, and how widely specific ancient works of art and texts were accessible — but they seek to avoid the positivism that frequently characterizes this scholarship. Much work on the classical tradition rests on the premise that ancient objects and texts bear single, authoritative, "true" meanings that were understood by all ancient audiences and that later viewers and readers either grasped correctly or failed to apprehend. ${ }^{2}$ This book instead considers all received meanings in all periods as constructs that are shaped by the receiver's "horizon of expectation" (to use the phrase of Hans Robert Jauss), a mindset conditioned by experiences within a particular cultural system. ${ }^{3}$ Our approach thus harmonizes with the famous formulation by Charles Martindale (in part based on the Rezeptionsästhetik of Jauss), "Meaning is always realized at the point of reception." ${ }^{4}$ In the late Middle Ages and Renaissance, this volume maintains, the collective aspects of the audience's "horizon of expectations" had already been informed by many earlier

\footnotetext{
${ }^{2}$ Even Anthony Grafton, Glenn W. Most, and Salvatore Settis, eds., The Classical Tradition (Cambridge, MA: Harvard University Press, 2010), vii, frame ancient Greek and Roman "cultural formations" as fixed entities with a "true" meaning: "The history of the reception of classical antiquity, as of any work of the human spirit, must balance, delicately and not unproblematically, between an unwavering commitment to uncovering as far as possible the truth of both ancient and modern cultural formations on the one hand and an undogmatic appreciation of the endless resourcefulness and inventiveness of human error on the other." On studies of Renaissance art that fall into the category of classical tradition scholarship, see the review of scholarship below.

${ }^{3}$ Hans Robert Jauss, Toward an Aesthetic of Reception, trans. Timothy Bahti (Minneapolis: University of Minnesota Press, 1982).

${ }^{4}$ Charles Martindale, Redeeming the Text (Cambridge: Cambridge University Press, 1993), 3. The editors and authors of the present volume recognize that we, too, bear our own "horizons of expectation," and that our interpretations of ancient and medieval and Renaissance works of art and texts are "mediated, situated, contingent" (to use the phrasing of Charles Martindale, "Introduction: Thinking Through Reception," Classics and the Uses of Reception, Blackwell Classical Receptions, ed. Martindale and Richard F. Thomas [Malden, MA: Blackwell, 2006], 1$14,3)$. We believe, however, that the material and textual remains of the past permit and even demand scholarship that grapples with "the-past-as-it-really-was," in this case the fourteenth, fifteenth, and sixteenth centuries in Europe.
} 
receptions of classical culture in Europe: during antiquity itself; during the early and high Middle Ages, especially (but not exclusively) under the influence of Christian thought; and during the late medieval and early modern periods under consideration here. ${ }^{5}$ This model of classical reception, in which later receptions are affected by earlier ones, is somewhat akin to Martindale's notion of "transhistoricism." Martindale, however, envisions a linear-and, in effect, patrilinear-relationship among great individual receivers through time ("ourselves reading Milton reading Virgil..."). By contrast, the present volume postulates that receivers in the late Middle Ages and Renaissance confronted ancient objects and texts whose meaning had been imprinted over time by a wide array of direct and indirect cultural forces. These receivers, moreover, interpreted and deployed the products of this transmission within their contemporary cultural matrix. The essays in this collection consider the interaction of classical reception in the visual arts of the fourteenth to sixteenth centuries with the dynamic political, social, intellectual, and artistic circumstances of these periods. In this respect, the collection aligns with the "cultural historical view of reception theory" espoused by Simon Goldhill. ${ }^{7}$ The contributors acknowledge, furthermore, that different receivers within a single culture may have experienced

\footnotetext{
${ }^{5}$ On classical reception within antiquity, see Hardwick 2003, 12-31, and James I. Porter, "Reception Studies: Future Prospects," in A Companion to Classical Receptions, Blackwell Companions to the Ancient World, ed. Lorna Hardwick and Christopher Stray (Malden, MA: Blackwell, 2011), 469-81, 471-3. On the reception of classical material culture during the full length of the medieval era, see below, "Review of Recent Scholarship." Isee Michael Greenhalgh, The Survival of Roman Antiquities in the Middle Ages (London: Duckworth, 1989). On the impact of earlier receptions of ancient art within the Renaissance on later ones, see, as a case study, Leonard Barkan, Unearthing the Past: Archaeology and Aesthetics in the Making of Renaissance Culture (New Haven, CT: Yale University Press, 1999), $2-16$, on the Belvedere Laocoön.

${ }^{6}$ Charles Martindale, "Reception - a new humanism? Receptivity, pedagogy, the transhistorical," Classical Receptions Journal 5 (2013), 169-83 (quote 172).

${ }^{7}$ Simon Goldhill, "Cultural History and Aesthetics: Why Kant is No Place to Start Reception Studies," in Theorising Performance: Greek Drama, Cultural History and Critics' Practice, ed. Edith Hall and S. Harrop (London: Duckworth, 2010), 56-70 (quote 69).
} 
strongly divergent reactions to works of art and texts (classical or otherwise), based on such factors as gender, social status, education, personal history, and individual taste. This principle derives from recent work in viewer reception theory, in part under the influence of feminist theory. ${ }^{8}$

This volume also adopts the feminist perspective that the dominant patriarchy at least sometimes deployed ancient art and texts to advance its agenda. ${ }^{9}$ The immense body of ancient visual and literary remains available in the fourteenth to sixteenth century held enormous potential for justifying and strengthening political and social control. In the feminist view, the high-status male culture of this period in Europe invested this classical inheritance with profound authority in part so that it could tap this potential. Of course, the mass of Greek and (mostly) Roman objects, monuments, and texts also posed a great challenge: Given its sheer scale, sweeping heterogeneity, and fragmentary state, the material demanded titanic efforts of categorization, interpretation, and assimilation before it could be marshaled to uphold and enforce patriarchal ideals and norms of conduct. Classical reception by upper-class educated men

\footnotetext{
${ }^{8}$ See, for instance, Norma Broude and Mary D. Garrard, "Introduction: Reclaiming Female Agency," in Reclaiming Female Agency: Feminist Art After Postmodernism, ed. Broude and Garrard (Berkeley, CA: University of California Press, 2005), 1-25, esp. 11-5, and Edith Hall, "Putting the Class into Classical Reception," in Companion to Classical Receptions, ed. Hardwick and Stray, 2011, 386-97; see in more depth below under "Review of Recent Scholarship."

${ }^{9}$ Articulating this feminist theoretical position generally for art history are Norma Broude and Mary D. Garrard, "Introduction: The Expanding Discourse," in Broude and Garrard, The Expanding Discourse, 1-26; Ibid., "Reclaiming Female Agency," 1-25. Specifically addressing the centuries under consideration here, but not primarily concerned with classical reception or visual culture, are Merry E. Wiesner-Hanks, Women and Gender in Early Modern Europe, 3rd ed., New Approaches to European History (Cambridge, UK: Carmbridge University Press, 2008), esp. 1-16; and Margaret W. Ferguson, Maureen Quilligan, and Nancy J. Vickers, Rewriting the Renaissance: The Discourses of Sexual Difference in Early Modern Europe (Chicago: University of Chicago Press, 1986). For fundamental studies on the patriarchal use of classical culture in fourteenth- to sixteenth-century European art, see below, "Review of Recent Scholarship."
} 
in these centuries - rulers, prelates, other male members of powerful families, scholars, artists, and authors, alongside women who embraced the prevailing agenda—represents for feminists an effort manage this process, to midwife the delivery of a "reborn" culture in line with the gender constructs that underlay contemporary power structures. ${ }^{10}$ The project was successful enough for historian Joan Kelly to ask in 1977, "Did women have a Renaissance?"11 Indeed, sixteenthcentury art historian Giorgio Vasari's characterization of his era as a rinascita following a period of decline after antiquity was integral to these masculinist endeavors. ${ }^{12}$ The continued use of the term "Renaissance" in current scholarship, then, is potentially problematic, since it adheres to an elite male formulation of history. The label "classical" reflects the same ideology, evoking an authoritative past culture to which enlightened men of more recent times have turned for inspiration. Out of convenience (and to avoid taxing the reader's patience by heavy repetition of "early modern," "ancient," and "antique"), the editors and authors of this volume do employ the terms "Renaissance" and "classical," but we recognize the gendered problematics of these names.

In addition, though, this collection of essays shows that powerful men of the fourteenth, fifteenth, and sixteenth centuries did not all approach classical art in the same way, and that women as patrons and viewers had the opportunity to construct potentially different gendered

\footnotetext{
${ }^{10}$ On this process in early modern Italy, see, for example, Marta Ajmar, "Exemplary Women in Renaissance Italy: Ambivalent Models of Behavior?," in Women in Italian Renaissance Culture and Society, ed. Letizia Panizza (Oxford: University of Oxford European Humanities Research Center, 2000), 244-64.

11 Joan Kelly, "Did Women Have a Renaissance?," in Women, History and Theory: The Essays of Joan Kelly (Chicago: University of Chicago Press, 1984), 19-51. Reprinted (writing as Joan Kelly-Gradol) from Becoming Visible: Women in European History, ed. Renate Bridenthal and Claudia Koonz (Boston, MA: Houghton Mifflin, 1977), 137-64.

${ }^{12}$ Giorgio Vasari, "Proemio delle Vite," in Le Vite de' più eccellenti pittori, scultori, $e$ architettori da Cimabue insino a' tempi nostri (Florence: Giunti, 1568). For the scholarship on Vasari's use of the term rinascita, see below, "Review of Recent Scholarship."
} 
meanings in their own encounters with the antique. The present volume examines a wide range of dynamics between classical receptions and gender constructs in the late Middle Ages and early modern era. The contributors, Mary D. Edwards, K. Sarah-Jane Murray with Ashley Simone, Genevieve S. Gessert, Stephanie C. Leone, Timothy B. Smith, Maria F. Maurer, April Oettinger, Patricia Simons, Hetty E. Joyce, Claudia Lazzaro, Ian Verstegen, and Katherine M. Bentz, address some of the ways in which artists, patrons, collectors, audiences, critics and other authors used antiquity as a basis for exploring, reinforcing, and/or unsettling contemporary notions about women and men as well as about individuals outside of these binary categories. The essays by Edwards, Murray and Simone, Leone, Maurer, Oettinger, Simons, Joyce, Lazzaro, and Verstegen uncover late medieval and Renaissance mores regarding gender roles and sexuality that underlie depictions of female figures from antiquity: goddesses, female personifications, mythical mortal women, (ostensibly) historical women, witches. Gessert, Oettinger, Lazzaro, and Bentz analyze how ancient visual and literary imagery was employed in the gendering of cities, fountains, gardens, and other abstract entities. Gessert and Smith consider the sometimes fluid interpretations of the gender of ancient statues and fragments. Leone, Maurer, and Joyce propose possible gendered receptions of ancient and classically informed works of art by individual viewers or groups of viewers. The visual culture of the fourteenth to sixteenth centuries, this collection contends, participated in myriad ways in the contemporary discourse on gender roles and identity, and the antique served as an important locus of this discourse for artists and their audiences.

\section{Review of Recent Scholarship}


This volume represents, to our knowledge, the first collection of essays situated at the nexus of classical reception, gender studies, and the history of European art from 1300 to 1600. It builds on a significant body of recent studies that deal with aspects of this multifaceted topic and also on a small number of groundbreaking publications by individual scholars that treat all three themes - responses to ancient culture, constructions of gender ideologies, and art. This literature review presents the scholarship in these areas that provides the most immediate context for the chapters that follow.

Numerous resources identify ancient objects that were accessible to artists, patrons, and collectors in the fourteenth to sixteenth centuries and provide information about how these objects were known and preserved. Literature treating the survival of antiquities is rarer for late medieval western Europe than for the early modern period; Michael Greenhalgh's book (1989) on the existence and recovery of ancient art in the Middle Ages, and the use of this material by medieval artists, remains a key text. ${ }^{13}$ The publications by Francis Haskell and Nicholas Penny (1982), Phyllis Pray Bober and Ruth Rubinstein (1986), and, recently, Kathleen Wren Christian (2010) have proved vital for scholars in this volume researching the use of antiquities in the Renaissance. ${ }^{14}$ Haskell and Penny's volume catalogued ninety-five canonical ancient sculptures

\footnotetext{
${ }^{13}$ Greenhalgh, The Survival of Roman Antiquities in the Middle Ages (London: Duckworth, 1989). For architectural re-use, see his Marble Past, Monumental Present: Building with Antiquities in the Medieval Mediterranean (Leiden: Brill, 2009). For an older study, see W. S. Heckscher, "Relics of Pagan Antiquity in Medieval Settings," Journal of the Warburg Institute 1, no. 3 (1938), 204-20.

${ }^{14}$ Francis Haskell and Nicholas Penny, Taste and the Antique: The Lure of Classical Sculpture 1500-1900 (New Haven and London: Yale University Press, 1981); Phyllis Bober and Ruth Rubinstein, Renaissance Artists and Antique Sculpture: A Handbook of Sources (Oxford and New York: Oxford University Press, 1986, Rev. ed. 2010); Kathleen Wren Christian, Empire Without End: Antiquities Collections in Renaissance Rome, c. 1350-1527 (New Haven: Yale University Press, 2010). For antiquities in and around Venice, see Irene Favaretto, Arte antica e cultura antiquaria nelle collezione venete al tempo della Serenissima (Rome: L'Erma di Bretschneider, 2002); in Venice and France, see Pomian Krzysztof, Collectors and Curiosities:
} 
and discussed their discovery, display, and changing reputations from 1500 to 1900 . Bober and Rubinstein's catalogue and its revised edition (2010) are print versions of their Census of Antique Works of Art Known in the Renaissance, which originated at the Warburg Institute in 1947 and is now also online. ${ }^{15}$ The entries in the census cover wide array of individual ancient objects, with information about the discoveries and their documentation, about textual references to the objects, and about visual records made by artists working from the year 1400 until the 1527 sack of Rome. In Christian's book and catalogue of Renaissance antiquities collections specifically in Rome (from the fourteenth century also until the sack of Rome), she presents detailed evidence of the holdings of thirty-seven Roman collections, accompanied by deeply researched contextual chapters that include investigations of the growth of antiquarianism in Rome, shifts in attitudes toward antiquities, and how collections were acquired. ${ }^{16}$

Establishing the "afterlife" of antiquities and artists' experiences of them has long been thought crucial in understanding how artistic cultures took shape and also how they changed, especially at the end of the Middle Ages and the beginning of the early modern period. In Boccaccio's Decameron (1348-51), the recently deceased Giotto is characterized as having revived the style of the ancients, bringing "back to light the art which had been buried under others' errors. . for centuries." ${ }^{17}$ Two centuries later, Vasari called the era in which he lived a

Paris and Venice. 1500-1800, trans. Elizabeth Wiles-Porter (Cambridge: Polity Press, 1990); for ancient coins known in the Renaissance, John Cunnally, Images of the Illustrious: The Numismatic Presence in the Renaissance (Princeton: Princeton University Press, 1999).

${ }^{15}$ The project was conceptualized by Fritz Saxl, Richard Krautheimer, and Karl Lehmann and executed by Phyllis Pray Bober and Ruth Rubinstein. Online database: http://www.census.de/census/home. ${ }^{16}$ See Bentz, Chap. 12 in this volume, $n .1$ for further sources on collections. 17 "Avendo egli quella arte ritornata in luce, che molti secoli sotto gli error d'alcuni, che piú a dilettar gli occhi degl'ignoranti che a compiacere allo 'ntelletto de' savi dipignendo, era stata sepulta," Decameron 6.5. This sentiment was echoed by Filippo Villani in his Liber de civitatis Florentiae famosis civibus in 1382. Nearly a century later, Lorenzo Ghiberti's Commentari (c. 
rinascita, presenting a chronological development of individual artists' styles and responses to ancient visual sources. ${ }^{18}$ Such founders of today's art history as Heinrich Wölfflin, Aby Warburg, Erwin Panofsky, and Ernst Gombrich influenced generations by drawing strong distinctions between medieval attitudes toward antiquities and Renaissance responses to these objects. ${ }^{19}$ Leonard Barkan's recent study, Unearthing the Past (1999), upholds this notion of difference in considering how and why archaeological sculptural finds were reused during the late fifteenth and sixteenth centuries in Italy, and in arguing that the "re-ordered fragments of past culture" contributed on a broad scale to Renaissance aesthetics and culture. ${ }^{20}$ Unlike most other far-reaching studies of the classical tradition in art, Barkan considers questions of both gender and audience. ${ }^{21}$

1450) charted a progression in which classical art represented an ideal and medieval art a decline, the latter ending when Giotto had re-introduced nature to art. For a thorough discussion of the concept of "Renaissance," see the article by Jill Kraye in Grafton, Most, and Settis, eds., The Classical Tradition, 810-5.

${ }^{18}$ For a problematization of the term rinascita, see Matteo Burioni, "Vasari's Rinascita: History, Anthropology, or Art Criticism?," in Renaissance? Perceptions of Continuity and Discontinuity in Europe, c. 1300- c.1550, ed. Alexander Lee and Pit Péporté (Leiden: Brill, 2008), 115-28. Ian Verstegen offers an analysis of Vasari's developmental but ahistorical concept of art in "Vasari's Progressive (But Non-Historicist) Renaissance," Journal of Art Historiography 5 (2011), 1-19. For valuable historiographical analyses of the constructs of classicism and of the Renaissance itself, see Salvatore Settis, Future of the Classical World, trans. Alan Cameron (Cambridge, MA: Polity, 2006), and Bryan A. Curran, "Teaching (And Thinking About) the High Renaissance: With Some Observations on its Relationship to Classical Antiquity," in Rethinking the High Renaissance, ed. Jill Burke (Farnham and Burlington: Ashgate, 2012), 27-55.

${ }^{19}$ Erwin Panofsky, Renaissance and Renascences in Western Art $2^{\text {nd }}$ ed. (New York: Harper and Row, 1972); E.H. Gombrich, Norm and Form: Studies in the Art of the Renaissance (London: Phaidon Press, 1966). Jill Burke, "Inventing the High Renaissance, from Winckelmann to Wikipedia: An Introductory Essay," in Burke, ed. Rethinking the High Renaissance, 11-3, and Christopher S. Wood, "Art History's Normative Renaissance," in The Italian Renaissance in the Twentieth Century, ed. Allen J. Grieco, Michael Rocke, and Fiorella Gioffredi Superbi (Florence: Olschki), 65-92.

${ }^{20}$ Barkan, Unearthing the Past, 271.

${ }^{21}$ E.g., in his discussions of hermaphrodite statues (see also Gessert and Smith in this volume, Chaps. 3, 5) and of the sleeping Ariadne/Cleopatra statue (see also Oettinger, Chap. 7): Barkan, Unearthing the Past, 164-6, 233-48. 
In addition to actual archaeological remains and finds, many artists and patrons

experienced ancient works of art through visual intermediaries - some themselves antique, some from more recent centuries, some contemporary—including coins, gems, drawings, manuscripts, printed books, and engravings. ${ }^{22} \mathrm{~A}$ theoretically multifaceted case study of this phenomenon is Adrian Randolph's Engaging Symbols (2002), which looks at small ancient bronzes and cameos as sources of inspiration for Donatello's David. ${ }^{23}$ Ancient texts provided information through description and ekphrasis about what ancient art looked like. In The Revival of the Olympian Gods in Renaissance Art (2003) and Classical Myths in Italian Renaissance Painting (2011), Luba Freedman argues that Renaissance painters employed close study of both ancient images and ancient literary descriptions to compose their classicizing artworks. ${ }^{24}$ For Renaissance readers, Pliny the Elder was the principal resource for the subjects, styles, and techniques of ancient art that no longer survived. Sarah McHam analyzes the relationship of Pliny's Natural History to early modern culture in a definitive volume published while this collection was coming together. ${ }^{25}$ Of the many lines of inquiry in McHam's wide-ranging book, those most germane to the present volume include the reception of the Natural History in antiquity; the impact of the text on thought and art in the Middle Ages; the role of fifteenth-century humanistic

${ }^{22}$ In this volume, see Gessert, Chap. 3; Smith, Chap. 5; Lazzaro, Chap. 10; Verstegen, Chap. 11; Bentz, Chap. 12. Categories of visual transmission in the printed or drawn examples beyond sculpture or architectural remains include allegories, emblemata, and astrology; see Malcolm Bull, The Mirror of the Gods: Classical Mythology in Renaissance Art (London and New York: Penguin, 2005), 7-36, and Ilaria Ramelli, "Ancient Allegory and its Reception through the Ages," International Journal of Classical Reception 18 no. 4 (2011), 569-78.

${ }^{23}$ Adrian W. B. Randolph, Engaging Symbols: Gender, Politics, and Public Art in FifteenthCentury Florence (New Haven: Yale University Press, 2002), 160-2.

${ }^{24}$ Luba Freedman, The Revival of the Olympian Gods in Renaissance Art (Cambridge and New York: Cambridge University Press, 2003); Ibid., Classical Myths in Italian Renaissance Painting (Cambridge and New York: Cambridge University Press, 2011).

${ }^{25}$ Sarah McHam, Pliny and the Artistic Culture of the Italian Renaissance (New Haven: Yale University Press, 2013). 
editions, translations, and commentaries in the formation of Renaissance culture; and the influence of sixteenth-century printed versions, especially in Northern Europe. Not only a source for what lost ancient art had looked like, the Natural History also helped to shape to the development of artistic theory, the competition among artists (with Pliny's characterization of the painter Apelles as a standard), and the relationships between artists and patrons, not to mention the humanist worldview as a whole.

McHam demonstrates that artistic receptions of Pliny went far beyond artists' simply replicating his descriptions, and art historians today accept that knowledge of actual antiquities was no more important to many Renaissance artists than other sources - perhaps sometimes even less so. Malcolm Bull argues in The Mirror of the Gods (2005) that medieval manuscripts such as the Ovide moralisé and early modern mythographies were more influential on later Renaissance artists than original Greek and Roman art. ${ }^{26}$ The text and printed illustrations of the Hypnerotomachia Poliphili were also important resources for artists, especially in Venice. ${ }^{27}$ The essays in the present volume also demonstrate that in addition to classical artworks, texts by Ovid, Virgil, Homer, Plato, Plutarch, Horace, Lucan, Livy, Philostratus the Elder, and many other ancient authors - known through medieval versions or "discovered" by humanists — were mined for subject matter by artists and patrons who may have had no intention of replicating

\footnotetext{
${ }^{26}$ Bull, The Mirror of the Gods. On the Ovide moralisé, see Murray with Simone, Chap. 2, and Joyce, Chap. 9 in this volume. Murray is currently translating the text into its first English translation and preparing a catalogue of the illuminations.

${ }^{27}$ See Oettinger, Chap. 7 in this volume. Rona Goffen, Titian's Women (New Haven: Yale University Press, 1997), 107-26 discusses how Venetian painters tended to be more interested in ancient conceptions of art than ancient art itself, and rarely exactly replicated styles or poses of ancient artworks. Patricia Fortini Brown, Venice and Antiquity: The Venetian Sense of the Past (New Haven: Yale University Press, 1997) explores Venice's lack of a classical past, and its invention and appropriation of one toward a civic identity.
} 
actual ancient artworks. ${ }^{28}$ The textual underpinnings of classicizing art have been a popular topic of scholarly inquiry, although in most cases gender and reception theory are not employed; exceptions will be discussed below. ${ }^{29}$

In their debate-inspiring work Anachronic Renaissance (2010), Alexander Nagel and Christopher Wood question the notion that truly ancient visual culture was at all significant for Renaissance artists. According to Nagel and Wood's paradigm of substitution, Renaissance artists and viewers often considered medieval and contemporary art to be ancient Greek or Roman; it would be more helpful, the authors argue, to have a resource of works that beholders thought to be Roman, such as the Florence Baptistery. ${ }^{30}$ Although Nagel and Wood's argument is compelling, we the volume editors, as scholars of classical art and reception, believe that in

${ }^{28}$ See Edwards, Chap. 1; Murray with Simone, Chap. 2; Leone, Chap. 4; Joyce, Chap. 9; Verstegen, Chap. 11.

${ }^{29}$ For the late medieval period, the scholarly corpus is sparser than for the early modern. Midtwentieth-century and later examples of studies considering ancient subject matter in medieval and/or Renaissance art that have not previously been cited include Walter Oakshott, Classical Inspiration in Medieval Art (New York: Frederick A. Praeger, 1960); Roberto Weiss, The Renaissance Discovery of Classical Antiquity (New York: Humanities Press, 1969; $2^{\text {nd }}$ ed. 1988); Salvatore Settis, ed. Memoria dell'antico nell'arte italiana, 3 vols. (Turin: Einaudi, 1984-6); Nikolaus Himmelmann, Antike Götter im Mittelalter (Mainz am Rhein: P. von Zabern, 1986), Charles Martindale, ed., Ovid Renewed: Ovidian Influences on Literature and Art from the Middle Ages to the Twentieth Century (Cambridge: Cambridge University Press, 1991); Jane Davidson Reid, ed., The Oxford Guide to Classical Mythology in the Arts, 1300-1990s, 2 vols. (New York: Oxford, 1993); Donna Kurtz, ed., Reception of Classical Art: An Introduction, Studies in Classical Archaeology, vol. 3. British Archaeological Reports, International Series 1295 (Oxford: Archaeopress, 2004); Karl Kilinski, Greek Myth and Western Art: The Presence of the Past (New York: Cambridge University Press, 2013). The topics of post-classical mythological subject matter and antique models have also come together in museum exhibitions, for example Brown University's Survival of the Gods: Classical Mythology in the Middle Ages in 1987; the Metropolitan Museum of Art's Man, Myth and Sensual Pleasures: Jan Gossart's Renaissance in 2010-2011; and the 2012 exhibition at the Liebieghaus Skulpturensammlung in Frankfurt, Zurück zur Klassik: Ein neuer Blick auf das alte Griechenland.

${ }^{30}$ Alexander Nagel and Christopher S. Wood, Anachronic Renaissance (New York: Zone Books, 2010). 
addition to knowing what was believed to be ancient, it is important to know when actual antiquities were excavated, known, and studied, and what the "afterlife" of these objects was. ${ }^{31}$

Often the ancient primary text source material was mediated, as the artwork was. In The Gothic Idol: Ideology and Image-Making in Medieval Art (1989), Michael Camille discusses the contrast between the Gothic conceptualization of images of ancient deities, "reconstituted from fragments of visual and verbal associations," and some relatively faithful early modern imitations of ancient subjects, a difference he attributes to medieval artists' considering various audience responses when composing imagery. ${ }^{32}$ Camille examines images of pagan idols within the context of the Church reinforcing its power over pagans, Jews, and Muslims, and he focuses on Christians' negatively associating antiquity with paganism. ${ }^{33}$ An influential book on the positive reception of ancient myth by medieval mythographers and the influence of these commentaries in the Renaissance was Jean Seznec's Survival of the Pagan Gods (first English edition 1953). Seznec looked at the transmission of early modern mythological subjects from earlier medieval writings and visual material, such as astrological books and tarot cards. Bull considers the same types of materials in domestic contexts, but he focuses on the decorative and escapist aspects of the imagery. ${ }^{34}$ By contrast, Joscelyn Godwin in The Pagan Dream of the Renaissance (2005) credits the popularity of images of the gods in early modern Italy, and then in Northern Europe, to a spiritual need for an alternate, "imaginal" world. ${ }^{35}$

${ }^{31}$ For example, Gessert, Smith, and Maurer, Chaps. 3, 5, and 6 in this volume, show how the adaptation of forms from ancient objects and fragments by Renaissance painters have important implications for ideas of gender construction.

${ }^{32}$ Camille, The Gothic Idol: Ideology and Image-making in Medieval Art (Cambridge: Cambridge University Press, 1989), 103, 114.

${ }^{33}$ In this volume, see Simons, Chap. 8 and Bentz, Chap. 12 for negative receptions of antiquity. ${ }^{34}$ Jean Seznec, Survival of the Pagan Gods, Barbara F. Sessions, trans. (Princeton: Princeton University Press, 1953.

${ }^{35}$ Joscelyn Godwin, The Pagan Dream of the Renaissance (Boston: Red Wheel/Weiser, 2005). 
Despite this wealth of scholarship, it is rare for art historians to frame their studies within the theoretical and methodological discourses of classical reception scholarship. ${ }^{36}$ Work by art historians is largely absent from conferences, journals, and edited volumes devoted to classical reception, even as scholarship regarding other artistic media, such as film, dance, poetry, and theater, has become an increasingly large presence in the field. ${ }^{37}$ Certainly, as we have seen, the study of artists "using" ancient art or subject matter is a deeply ingrained part of art history, but this approach comes from within the discipline, and its practitioners are usually trained in the art of the receiving period but not in classical reception studies. ${ }^{38}$ There has been a growth in studies considering reception in general, however, which has broadened notions of audience and response. In this context, reception is the way a particular viewer or type of viewer reacts to a specific work of art or display.

Much art-historical reception theory has arisen in concert with feminist and gender-based theoretical approaches that expanded the canon and the category "artist." The present volume owes a significant debt to late twentieth-century feminist studies that shifted the focus of medieval and early modern scholarship from paintings and sculptures mostly by male artists for

\footnotetext{
${ }^{36}$ In Alina Payne, Ann Kuttner, and Rebekah Schmicks, eds. Antiquity and its Interpreters, $2^{\text {nd }}$ ed. (London and New York: Cambridge University Press, 2012), the introduction and some of the contributions show an affinity for the type of scholarship practiced in classical reception studies, but the editors use Barkan's term "transumption" for the cultural borrowing of classical material or style (2). Most of the essays in Antiquity and its Interpreters focus on architecture or ekphrases, not on gender constructions, although the book is similar to the present volume as a collaborative project among specialists of the arts of ancient Rome and of early modern periods. ${ }^{37}$ For example, Hardwick and Stray, Companion to Classical Receptions, includes sections for Performing Arts and Film, but not one for Visual Arts. The International Conference on two of the themes of this volume, "Classical Greek and Roman Literature: Gendered Perspectives in Reading and Reception," University of Maryland, College Park, April 1, 2012, included no art history papers.

${ }^{38}$ Numerous university Classics departments now offer discrete degrees in Classical Reception, the impact of which will be seen as their graduates become active in the discipline.
} 
elite male patrons to a broader canon that included art produced, commissioned, and/or used by women. ${ }^{39}$ Feminists examined so-called "popular," "minor," or “applied” arts, such as deschi da parto (painted trays given to women upon childbirth), cassoni (painted wedding chests), maiolica, and tapestries. For the medieval period, Jeffrey Hamburger's publications on previously ignored manuscripts and drawings made by religious women for their own contemplation are essential contributions. ${ }^{40}$ Important recent scholarship on less-studied media within the early modern period include Christiane Klapisch-Zuber's work on holy dolls, Jacqueline Marie Musacchio's book on deschi da parto, and Cristelle Baskins's milestone study of cassoni (painted wedding chests). ${ }^{41}$

Feminist art historians have also adopted Laura Mulvey's conception of the gaze, which postulates an assumed male perspective in viewing, to consider gazes directed toward images of women, as in several essays in Norma Broude and Mary Garrard's edited collection The Expanding Discourse: Feminism and Art History (1992) — the first compilation of feminist arthistorical scholarship. ${ }^{42}$ The essays in Expanding Discourse cover a range of periods, from the early modern era to the late twentieth century, and include several groundbreaking articles on

\footnotetext{
${ }^{39}$ Two groundbreaking, now classic, texts bringing attention to women artists were Linda Nochlin, "Why Have There Been No Great Women Artists," ARTnews 69 (1971): 22-39, 67-71, and Griselda Pollack, Old Mistresses: Women, Art, and Ideology (London: Routledge and Kegan Paul, 1981).

${ }^{40}$ Jeffrey Hamburger, The Rothschild Canticles: Art and Mysticism in Flanders and the Rhineland circa 1300 (New Haven: Yale University Press), and Nuns as Artist: The Visual Culture of a Medieval Convent (Berkeley: University of California Press, 1997).

${ }^{41}$ Christiane Klapisch-Zuber, Women, Family, and Ritual in the Renaissance, trans. Lydia G. Cochrane (Chicago: Chicago University Press, 1985); Jacqueline Marie Musacchio, The Art and Ritual of Childbirth in Renaissance Italy (New Haven: Yale University Press, 1999); Cristelle Baskins, Cassone Painting, Humanism and Gender in Early Modern Italy (London and New York: Cambridge University Press, 1998).

${ }^{42}$ Laura Mulvey, "Visual Pleasure and Narrative Cinema," Screen 16 no. 3 (1975), 6-18. Norma Broude and Mary Garrard, eds., The Expanding Discourse: Feminism and Art History (Boulder, CO: Westview Press, 1992).
} 
fifteenth- and sixteenth-century art. There is now a substantial corpus of scholarship on female artists, female patronage, and portraits of women in the early modern period, as evidenced by the essays and bibliographies in the 2013 Ashgate Research Companion to Women and Gender in Early Modern Europe.$^{43}$ Feminist approaches in late medieval art history have been more rare, although this situation is changing. ${ }^{44}$ Not only Jeffrey Hamburger but also Madeline Caviness and Linda Seidel consider women's agency and reception in the Middle Ages, although antique revival is not one of their topics of inquiry. ${ }^{45}$

Masculinity studies and queer theory have interrogated the gaze in other ways, addressing the assumed heteronormativity of artist, subject, and viewer. In this respect, the inclusion of the term "gender" in the title of Ashgate's 2013 compilation is telling. ${ }^{46}$ James Saslow's Ganymede in the Renaissance, a pioneering work in queer theory, explores early modern attitudes towards homoeroticism and gender through the lens of contemporary Ganymede imagery. ${ }^{47}$ Patricia

\footnotetext{
${ }^{43}$ Allyson M. Poska, Jane Couchman, and Katherine A. McIver, eds., The Ashgate Research Companion to Women and Gender in Early Modern Europe (Farnham and Burlington: Ashgate, 2013. For patronage, see also Sheryl E. Reiss and David G. Wilkins, eds. Beyond Isabella: Secular Women Patrons of Art in Renaissance Italy (Kirksville, MO: Truman State University Press, 2001). Paola Tinagli, Women in Italian Renaissance Art: Gender, Patronage, and Identity (Manchester: Manchester University Press, 1997) considers portraits of women and their receptions by women, but consciously rejects a feminist approach.

${ }^{44}$ See Rachel Dressler, "Continuing the Discourse: Feminist Scholarship and the Study of Medieval Visual Culture," Medieval Feminist Forum 43 no. 1 (2007): 15-34, and Marian Bleeke, "Feminist Approaches to Medieval Visual Culture: An Introduction," Medieval Feminist Forum 22 no. 2 (2008), 49-52.

${ }^{45}$ Major works include Madeline H. Caviness, Visualizing Women in the Middle Ages: Sight, Spectacle and Scopic Economy (Philadelphia: University of Pennsylvania Press, 2001); Linda Seidel, Jan van Eyck's Arnolfini Portrait: Stories of an Icon (Cambridge: Cambridge University Press, 1995).

${ }^{46}$ There is also now Ashgate's Women and Gender in the Early Modern World book series, and the University of Chicago Press's series The Other Voice in Early Modern Europe. See Merry E. Wiesner-Hanks, Women and Gender, for an overview of gender-based approaches.

${ }^{47}$ James Saslow, Ganymede in the Renaissance: Homosexuality in Art and Society (New Haven and London: Yale, University Press, 1986); see also his "Michelangelo: Sculpture, Sex, and
} 
Simons, a contributor to the present collection, treats the complicated masculinity of Hercules and potentially homosexualizing receptions of Diana and her nymphs in Renaissance art. ${ }^{48}$ Their landmark studies have expanded inquiry on the interrelationships of gender, classics, and reception. Queer theory, viewer reception studies, and classical reception also come together in Randolph's aforementioned study of Donatello's David, where he considers a homosocial reading. ${ }^{49}$

Other scholarship in medieval and early modern studies has also considered viewer reception in ways that are relevant here. In his Pagan Idol, Camille rejects Panofsky's characterization of the relationship between medieval and ancient art as a "disjunction." Camille presents medieval art as a purposeful re-interpretation that would have been understood in various ways. ${ }^{50}$ A number of collected volumes on medieval and early modern art and literature include essays on gender and viewership (but not on classical reception), notably Margaret Ferguson, Maureen Quilligan, and Nancy Vickers's Rewriting the Renaissance (1986); Marilyn Migiel and Juliana Schiesari's Refiguring Woman (1991); Geraldine Johnson and Sara Matthews Grieco's Picturing Women in Renaissance and Baroque Italy (1997), many chapters of which consider domestic religious or secular art within the context of power relations in the household; and Sherry Lindquist's The Meanings of Nudity in Medieval Art (2012). ${ }^{51}$

Gender," in Looking at Italian Renaissance Sculpture, ed. Sara Blake McHam (New York: Cambridge University Press, 1998), 223-45.

${ }^{48}$ Patricia Simons, "Hercules in Italian Renaissance Art: Masculine Labour and Homoerotic Libido," Art History 31 (2008), 632-64, and "Lesbian (In)Visibility in Italian Renaissance Culture: Diana and Other Cases of Donna con Donna," Journal of Homosexuality 27, no. 1-2 (1994), 81-122.

${ }^{49}$ Engaging Symbols, 183-90. Chapters in this volume that look at ancient images destabilizing gender include Edwards, Chap. 1; Smith, Chap. 5; and Maurer, Chap. 6.

${ }^{50}$ Gothic Idol, 101-7.

${ }^{51}$ Ferguson, Quilligan, and Vickers, eds., Rewriting the Renaissance; Marilyn Migiel and Juliana Schiesari, eds., Refiguring Woman: Perspectives on Gender and the Italian Renaissance (Ithaca: 
Although the present book is the first edited volume to consider antiquity and gender together in late medieval and Renaissance art, some individual studies have pursued this tack in recent decades (even if not expressly adopting the framework of classical reception). Saslow's work on Ganymede and Simons's on Hercules and Diana are important examples.$^{52}$ Other historians of medieval and early modern art have applied feminist or queer theory to examine how male artists and patrons used mythological subject matter or classicizing formal language to define normative gender roles; to maintain or create political dominance through public art; to enforce patriarchal family structures; to attract or meet erotic gazes, oppose paganism, promote ideal marriage, uphold Christianity, or consider beauty, love, or art itself. A few case studies will serve here to illustrate the different avenues of approach that have been taken-avenues explored in this volume as well.

An early model of art-historical scholarship on state-sponsored public art promoting female subjugation through classicizing rhetoric, albeit in Augustan Rome and eighteenthcentury Europe, was pioneer feminist classicist Natalie Boymel Kampen's article "The Muted Other" in The Expanding Discourse. Kampen's essay articulates the theoretical principle, "The classical rhetoric of gender in works of art is, like the choice of the period deemed classic, the staking out of an ideological position.. ${ }^{.53}$ Renaissance public art depicting subjects from antiquity and/or employing a classicizing style has become a locus of scholarship on gender construction.

Cornell University Press, 1991); Geraldine A. Johnson and Sara F. Matthews Grieco, eds., Picturing Women in Renaissance and Baroque Italy (New York: Cambridge University Press, 1997); Sherry C. M. Lindquist, The Meanings of Nudity in Medieval Art (Burlington, VT: Ashgate, 2012).

${ }^{52}$ Saslow, Ganymede in the Renaissance; Simons, "Hercules in Italian Renaissance Art"; Ibid., "Lesbian (In)Visibility in Italian Renaissance Culture."

${ }^{53}$ Natalie Boymel Kampen, "The Muted Other: Gender and Morality in Augustan Rome and Eighteenth-Century Europe," in Broude and Garrard, Expanding Discourse, 161-70 (quote 161). 
Also in The Expanding Discourse, Yael Even discussed the replacement of Donatello's Judith and Holofernes by Benvenuto Cellini's Perseus Slaying Medusa (1545-54) in the Piazza della Signoria in Florence, and the addition of Giambologna's Rape of the Sabine Women in 1582, as symbolizing the masculine power of the city's rulers and the promotion of their aggressive approach to civic duties ${ }^{54}$ Geraldine Johnson in Picturing Women looks at how the increase of classical subject matter concerning male violence against women, including these statue groups, paralleled the increasing limitation of women's participation in public roles. ${ }^{55}$ Adrian Randolph accepts the arguments of Even and Johnson as important ones, but he also takes into account possible positive female responses to the statues. His Engaging Symbols examines how fifteenthcentury Florentine rulers used ancient sources to create gendered symbols of Florence, of themselves, and of their rule, and considers how differently gendered viewers may have received them. ${ }^{56}$ Randolph posits the theoretical standpoint that representations of gender, "rather than reflecting socio-historical relations, exist in a complicated mobile pattern of exchange, linking production, reception, and circulation, within particular contexts." Florentine political art possessed a dialogic function, he contends, in shaping public opinion of the state. ${ }^{57}$

Another topic of inquiry that has proven fruitful concerning the reception of antiquity and the formulation of gender in early modern art is the conceptualization of the natural realm. Mary Garrard, in her far-reaching Brunelleschi's Egg (2010), traces the history of the nature-female /

\footnotetext{
${ }^{54}$ Yael Even, "The Loggia dei Lanzi: A Showcase of Female Subjugation," in Broude and Garrard, Expanding Discourse, 127-37. See also Elena Cileltti. "Patriarchal Ideology in the Renaissance Iconography of Judith," in Migiel and Schiesari, Refiguring Women, 35-70. ${ }^{55}$ Geraldine Johnson, "Idol or Ideal: The Power and Potency of Female Public Sculpture," in Johnson and Grieco, Picturing Women, 239-44.

${ }^{56}$ Randolph, Engaging Symbols.

${ }^{57}$ Randolph, Engaging Symbols (quote 246). Lazzaro, in this volume's Chap. 10, examines the gendering of personifications of Florence in sixteenth-century art as both male and female.
} 
culture-male dichotomy from its prehistoric origins in the Ancient Near East to its adoption and interpretation by the patriarchy in fifteenth- and sixteenth-century Italian art, science, and letters. Garrard uses feminist theory to interrogate masculinist biases in traditional art-historical approaches to many canonical artists and artworks. She finds that antiquity played a role in constructing this elite male definition of art and nature both in the Renaissance and in modern art-historical scholarship. The austere style of early Renaissance art as practiced by Masaccio, deemed classicizing by sixteenth-century critics as well as by twentieth-century art historians, provided a "gender-inflected value," Garrard argues. Associated with humanist values of individualism, progress, and heroism, this style was viewed in contrast to female-gendered nature, and to the decorative International style of Gentile da Fabriano, which accordingly came to be seen as weak and effeminate. ${ }^{58}$ Among other gendered sites, Garrard looks at gardens, adducing the passivity of female garden statues to show an increasing debasement of images relating to Natura. ${ }^{59}$ In Garrard's view, early modern artists imitated monumental ancient art with idealized styles because these works of art were seen to be examples of man's perfection of —and therefore displacement of-nature. ${ }^{60}$ Claudia Lazzaro, another contributor to the present volume, addresses the interaction of mythological subjects and personifications in Renaissance gardens with contemporary perceptions of gender. In an influential article first published in Refiguring Women, Lazzaro treats the identity of sculpted figures and other signs in gardens as coded female or male, following contemporary gender ideology that accepted Aristotle's nature-

\footnotetext{
${ }^{58}$ Mary D. Garrard, Brunelleschi's Egg: Nature, Art, and Gender in Renaissance Italy (Berkeley: University of California Press, 2010), 73.

${ }^{59}$ Ibid., 275.

${ }^{60}$ Ibid., 241.
} 
female, culture-male dichotomy ${ }^{61}$ Subjects gendered female, such as Tellus, Terra Mater, and Cybele, emphasized sensuality and fertility with their bodies and poses, whereas male personifications and gods, such as Oceanus and Neptune, appeared more powerful and active. Lazzaro argues that gardens did not symbolize man's domination over nature, as modern scholarship has held, but rather a symbiotic relationship between the two, exemplified by the complementary pairings of statues of different genders. ${ }^{62}$

The deployment of classicism within the private sphere to express gendered power has also been the subject of studies that consider viewer reception. Stephanie Schrader, for example, discusses Jan Gossart's use of nude mythological subjects to communicate the sexual and political power of his patron, Philip of Burgundy. ${ }^{63}$ Titian's Venus of Urbino, in which the goddess occupies a contemporary domestic interior, has prompted a number of theoretical approaches. ${ }^{64}$ Most notably, Rona Goffen linked the sensual nude figure to contemporary ideals of wifely love and to notions of possession by patron, artist, and/or audience. ${ }^{65}$ Luba Freedman treats sixteenth-century images of single pagan deities in statuary and other media within the context of Italian male elite patrons displaying their status through art in their homes. ${ }^{66}$ Cristelle

${ }^{61}$ Claudia Lazzaro, "The Visual Language of Gender in Sixteenth-Century Garden Sculpture," in Migiel and Schiesari, Refiguring Women, 71-113; a revised version, "Gendered Nature and Its Representation in Sixteenth-Century Garden Sculpture," appears in Looking at Italian Renaissance Sculpture, ed. Sarah McHam (Cambridge: Cambridge University Press, 1998), 24673.

${ }^{62}$ See Oettinger, Chap. 7, as gardens as places of inspiration, and Bentz, Chap. 12, for associations between gardens and female sexuality.

${ }^{63}$ Stephanie Schrader, "Gossart's Mythological Nudes and the Shaping of Philip of Burgundy's Erotic Identity," in Man, Myth and Sensual Pleasures: Jan Gossart's Renaissance, ed. Maryan W. Ainsworth (New York: Metropolitan Museum of Art, 2010), 57-67.

${ }^{64}$ See the collection edited by Goffen, Titian's Venus of Urbino (Cambridge: Cambridge University Press, 1997); Garrard, Brunelleschi's Egg, 199-204.

${ }^{65}$ Goffen, Titian's Women, 146-57. Garrard offers a contrary reading, she sees in this Venus not only the goddess of the marital bed, but also the patron of courtesans.

${ }^{66}$ Freedman, Revival of the Olympian Gods. 
Baskins employs a wide variety of methodologies, including gender and reception theory, in examining non-canonical cassone paintings and their depictions of female "heroines" from ancient literature: Amazons, Dido, Camilla, the Sabine women, Lucretia, and Virginia ${ }^{67}$ In a tour de force of interdisciplinary scholarship and theoretical interplay, Baskins looks at the potentially contradictory messages of the imagery — which is often assumed to be moralizing and proposes multiple readings by audiences of differing social classes, genders, and ages. ${ }^{68}$ The paintings, Baskins argues, helped to socialize the newlyweds into the male-dominated culture, but they could also challenge male authority and normative gender roles. Stephen Campbell's Cabinet of Eros (2004) also adopts a broad socio-historical approach, applying it to the collecting of art by a specific historical individual: Isabella d'Este, marchesa of Mantua ${ }^{69}$ In his examination of Isabella's studiolo and its program of mythological paintings, Campbell addresses female viewership and agency, gendered space, and the adaptation of classical subject matter within the humanistic and literary cultural context of the Gonzaga court. ${ }^{70}$ Campbell does not explicitly use feminist or reception theory, but his consideration of the studiolo collection as means to inspire reflection on beauty and art calls to mind Leonard Barkan's statement, "It is not only politics, society, and economics that generate the impulse of art; it is also art itself.",71

\footnotetext{
${ }^{67}$ Baskins, Cassone Painting. See in this volume Stephanie Leone, Chapter 4, for a more detailed discussion of Baskins' methodology.

${ }^{68}$ A potentially conflicting view of a wife's role with regard to the patriline through depiction of a non-heroic classical subject is also discussed by Verstegen in this volume, Chap. 11. Simons, Chap. 8, discusses contradictions in views of women's sexuality and their presentations as antiheroines: witches.

${ }^{69}$ Stephen Campbell, The Cabinet of Eros: Renaissance Mythological Painting and the Studiolo of Isabella d'Este (New Haven and London: Yale University Press, 2004).

${ }^{70}$ See Maurer's Chap. 6 in this volume on three later mythological commissions by the Gonzaga family; and Edwards, Chap. 1; Leone, Chap. 4; Maurer, Chap. 6; and Verstegen, Chap. 11 for studies that concentrate on one patron or one group of patrons and viewers.

${ }^{71}$ Barkan, Unearthing the Past, xxxii.
} 
The present book therefore emerges out of a vital, methodologically diverse body of scholarship on responses to antiquity in, and/or contributions to contemporary gender discourses by, the artistic cultures of late medieval and early modern Europe. As the first collection of essays on all three of these topics, the present volume illustrates the range of approaches that are possible in engaging with this set of questions. It also allows a number of profound thematic interconnections to arise among the individual studies (see "Thematic Threads," below), delineating avenues of inquiry along which further work in this field might potentially coalesce. Finally, this book represents the product of collaboration among theorists and scholars of the received and receiving cultures. Feminist art historians have long called for scholars to work together, and Lorna Hardwick has recently emphasized the importance of collaboration in classical reception studies. ${ }^{72}$ The editors and authors of this collection include classical archaeologists, late antique art historians, a medieval literature specialist, medieval art historians, and early modern art historians, some with a background in classical reception, some in feminist or queer theory, and some in both. The strong spirit of collaboration within this group was crucial, we submit, to the success of the project. We hope that the volume spurs further research — perhaps also collaborative in nature — at the convergence of classical reception, gender studies, and the history of art.

\section{The Essays}

The present collection focuses most extensively on the artistic culture of the Italian Renaissance, but it also looks at aspects of late medieval and Northern Renaissance art. The arrangement of

\footnotetext{
${ }^{72}$ Lorna Hardwick, "Editorial," Classical Receptions Journal 2 (2010), 1-3: 1. Natalie Boymel Kampen, "On Writing Histories of Roman Art," Art Bulletin 85 (2003), 373-83, emphasizes the value of interdisciplinarity and collaboration.
} 
the chapters is roughly chronological, beginning with the early fourteenth century and concluding with the late sixteenth century (although some essays cover a significant span of time within these parameters). Since the subject of architecture would raise other theoretical and analytical issues, the volume focuses only on art; the authors do, however, consider the relationships between works of art and their architectural contexts.

In Chapter 1, “Cross-Dressing in the Arena Chapel: Giotto’s Virtue Fortitude ReExamined," Mary D. Edwards argues that the famous fresco cycle by Giotto in the Arena Chapel in Padua (c. 1305-6) assimilates the armed personification of Fortitude to the mythical Omphale by portraying the female Virtue in the lion skin of Hercules. Edwards proposes that for the patron of the Arena Chapel, the money-changer Enrico Scrovegni, Giotto's Fortitude may have evoked Hercules and Omphale simultaneously. The hero Hercules, compared by some medieval authors to Christ, but tainted by having killed his family (or members of it) in a fit of madness, stood for Enrico the usurer; Omphale, the source of expiation for Hercules through her enslavement of the hero, embodied Enrico's hopes for Christian salvation. The wealthy male patron thus linked himself visually with a mythical queen as an expression of Christian penance. Edwards looks closely at the vigorous humanist culture of Padua in the early thirteenth century, arguing that at least one of the multiple ancient textual sources of the Omphale myth was likely accessible to Enrico, Giotto, and/or the designer of the Arena Chapel fresco program (Altegrado Cattaneo di Lendinara?).

K. Sarah-Jane Murray and Ashley A. Simone consider the role of Europa in early illustrated manuscripts of the Ovide moralisé in Chapter 2, "The Liminal Feminine: Illuminating Europa in the Ovide Moralisé." A massive text comprising the Metamorphoses and an early fourteenth-century Christian allegorical commentary, the Ovide moralisé provided one of the 
principal means by which Ovid's text was received by late medieval and Renaissance thinkers and artists (see, for example, Maurer, Chapter 6, on Renaissance depictions of Pasiphaë, and Joyce, Chapter 9, on late medieval and early modern Philomela imagery). Murray and Simone focus on two early illustrated Ovide Moralisé manuscripts, Rouen Bibliothèque Municipal MS 0.4 and Paris Bibliothèque de l'Arsenal MS 5069, each of which includes a miniature of Europa, the princess of Tyre taken by Jupiter in the guise of a bull. Ultimately derived from ancient images of Europa riding on the bull's back, the illustration is juxtaposed in both cases with a Christological scene. Murray and Simone closely analyze the Old French text and its gendering of Jupiter, who first transforms into a castrated ox and then, once Europa touches him, into a bull. Such language, they argue, when combined with the imagery of Christ, suggests that the figure of Europa abducted by Jupiter represents the Christian soul in its union with Christ.

In Chapter 3, "A Giant Corrupt Body: The Gendering of Renaissance Roma," Genevieve S. Gessert finds links between representations of the city of Rome in early modern literature and art, such as Poggio Bracciolini's De varietate fortunae (second quarter of the fifteenth century), and receptions by contemporary humanists and artists of hermaphroditic figures in ancient sculpture. The varied responses to images of hermaphrodites, and to statues of other figures that were assigned intersexual status, shared in common a strong desire to investigate and understand - to excavate - the hybrid body. Characterizations of Rome, Gessert argues, attributed both male and female qualities to the city as well: The trope of Roma as a corpse (instar gigantei cadaveris corrupti, in Poggio's words) left the gender of the city open to intersexual readings. Like hermaphroditic statues, this mixed-gender body demanded exploration.

Stephanie C. Leone considers the potential meanings for elite viewers Vittoria Piccolomini, Borghese Petrucci, and Aurelia Petrucci of Luca Signorelli’s fresco Veturia 
Persuading Coriolanus to Spare Rome (c. 1509-11) in their family palace in Siena. In Chapter 4, “Luca Signorelli’s Veturia Persuading Coriolanus to Spare Rome and Viewers in the Palazzo Petrucci, Siena," Leone draws on reader and viewer reception theory to postulate disparate responses to Signorelli's rendering of this possibly legendary event in early Roman history. Leone notes that the active role played in this scene by the matron Veturia in admonishing her son Coriolanus not to attack his native Rome departs from ideals of women's submissiveness in early modern Italy. For the newly married Vittoria, Leone argues, the figure of Veturia may have offered a nuanced picture of women's agency within the elite family, and even within the public sphere. For her groom, Borghese Petrucci, the story of Coriolanus may have resonated with contemporary expectations that the marrying man tame his innate wildness and become an upstanding citizen. A generation later, for their daughter Aurelia, who garnered recognition as a poet, the painting may have celebrated the power of female speech.

Timothy B. Smith discerns gender ambiguity in some Cinquecento drawings and engravings of the Torso Belvedere and in a figure dependent on this famous ancient fragment: the decapitated criminal in Sodoma's fresco The Execution of Niccolò di Tuldo (completed 1526). Smith proposes in Chapter 5, "Queer Fragments: Sodoma, the Belvedere Torso, and Saint Catherine's Head," that the incomplete state of the Torso may have encouraged Renaissance receivers to see gender slippage in the statue, despite its bulging musculature. The Renaissance identification of the Torso as Hercules, Smith submits, may have sometimes called to mind the hero's deviation from conventional male roles in his submission to Omphale (a subject also invoked, as Edwards proposes in Chapter 1, by Giotto's Fortitude). Sodoma exploited this gender fluidity of the Torso, Smith argues, to downplay the masculinity of his headless Niccolò. The decapitation scene, which decorates the chapel of Saint Catherine of Siena in her hometown, 
invites viewers to associate Niccolò's body with the female saint's head relic, displayed in the same space. In this context, Smith contends, Sodoma's fresco resonates with a letter by Catherine describing the execution in language that inverts the gender of the convict and of the saint.

Maria F. Maurer examines a fresco in the Palazzo del Te by Giulio Romano and two maiolica dishes attributed to Nicola da Urbino (all 1520s) depicting the myth of Pasiphaë, the Cretan queen who commissioned a wooden cow costume from the craftsman Daedalus to consummate her love for a bull. In Chapter 6, "The Trouble with Pasiphaë: Engendering a Myth at the Gonzaga Court," Maurer discusses the multiple possible responses to this imagery among the elite men and women dining with Federico II Gonzaga in his palace at Mantua. The artists, Maurer suggests, drew on a wide range of sources, among them numerous ancient literary versions of the Pasiphaë myth; more recent translations and commentaries of these works, including the Ovide moralisé; an antique Pasiphaë sarcophagus relief in Rome; a fresco by Baldassare Peruzzi on the façade of the Villa Farnesina in Rome; and, for the wall painting, ancient images of male figures subjugating wild beasts, including a relief of Mithras and the Bull that was frequently identified by contemporaries as a Hercules scene. Like Edwards (Chapter 1) and Smith (Chapter 5), Maurer finds a likely use of ancient Hercules imagery to complicate the gender of a figure, in this case to highlight Pasiphaë's deviation from traditional sexual roles for women. The Mantuan fresco and maiolica plates, Maurer proposes, could serve as a warning against lustfulness in women, as a source of titillation for men, and as a basis for thoughts and conversation on - perhaps even engagement in — a range of behavior, including the exploration of various sexual roles by both men and women. 
April Oettinger links Lorenzo Lotto's panel painting Venus and Cupid (Venice, late 1520 s) with the trope of the fountain nymph in classicizing Renaissance texts and images. In Chapter 7, "Vision, Voluptas, and the Poetics of Water in Lorenzo Lotto's Venus and Cupid," Oettinger argues that the image of Cupid urinating on the nude Venus, who reclines on a blue cloth, evokes two fountains in the antiquarian romance Hypnerotomachia Poliphili of 1499, the first fed by a sleeping female statue, the second by a puer mingens figure. Oettinger also connects Lotto's image to the nymph lulled to sleep by trickling waters in the fifteenth-century pseudo-classical epigram Huius Nympha Loci. The Nymph of the Spring motif recurs, Oettinger argues, not only in Renaissance fountain displays but also in paintings by Italian and northern European artists that depict recumbent female figures in mythological landscapes with springs. Oettinger interprets the Nymph of the Spring and, by extension, the Venus and Cupid as an allegory of poetic inspiration: Lotto's Venus embodies the pleasure, the voluptas, of a beholder's encounter with art. In engaging with and reinforcing the early modern understanding of fountains and springs as feminine, the Venus and Cupid joined an array of Renaissance classical receptions that contributed to a gendered view of nature (another being the criticism of antique statues in gardens: See Bentz, Chapter 12).

In Chapter 8, "The Crone, the Witch, and the Library: The Intersection of Classical Fantasy with Christian Vice during the Italian Renaissance," Patricia Simons brings into focus the roles played by ancient witches and other fearsome female figures from antiquity in the construction of early modern stereotypes of the witch, particularly in Italian art and texts of the decades around 1500. The pagan world, Simons notes, was not always a font of inspiration and beauty for Renaissance artists and authors; it could also hold danger and ugliness. The art of witchcraft was "ancient in essence," according to Giovanfrancesco Pico della Mirandola (Strix, 
1523). Simons looks closely at the horrid, aged witches in Italian Renaissance paintings and prints set within classical contexts, such as the Stregozzo engraved by Agostino Veneziano in c. 1515-25, finding in these figures a mingling of attributes that in antiquity had been associated with the crone (the grotesque old woman without supernatural powers), personified Envy, the Fates, the Furies, and Medusa. Such visual and literary portrayals, Simons reminds the reader, appeared against a backdrop of actual trials and executions of accused witches, and the classical allusions helped to create a distancing effect for the viewer from these "dangerous" women. On the other hand, some witches with ancient origins could be young, lovely figures, objects of fascination and of the desiring male gaze, such as Dosso Dossi's Circe of c. 1511-25.

Hetty E. Joyce, in Chapter 9, "Picturing Rape and Revenge in Ovid's Myth of Philomela," traces the history of Ovidian Philomela scenes from the late Middle Ages through the end of the sixteenth century in manuscripts (including the Rouen and Arsenal copies of the Ovide moralisé discussed by Murray and Simone in Chapter 1), in printed books, and in a set of English or French Renaissance embroidered bed valances of c. 1600. Joyce analyzes the ways in which these images, usually composing cycles of two or more episodes, relate to Ovid's version of the myth of Philomela, the Athenian princess whose brother-in-law, King Tereus of Thrace, imprisoned and raped her, then cut out her tongue. In Ovid's telling, Philomela alerted her sister, Queen Procne, by weaving a tapestry with an encoded message; Procne liberated her, and the sisters served Tereus his dismembered son in revenge. Recent feminist scholarship focuses on Philomela's weaving, but except for the bed hangings, Joyce points out, the late medieval and early modern images do not include this scene. The rape also appears quite late, the tonguecutting serving in its place in earlier illustrations to convey Tereus' brutality. On the bed valances, likely embroidered by and for a woman of high rank, the representation of Philomela's 
tapestry with its secret notae for Procne may have offered its artist, patron, or both a celebration of the agency and solidarity of needleworking noble ladies. Maurer in Chapter 6 and Verstegen in Chapter 11 also consider the possibility of viewers ascribing agency to mythological women who do not adopt traditionally heroic roles: Pasiphaë at Mantua (Maurer) and Creusa in Barocci’s Aeneas' Flight from Troy (Verstegen).

Claudia Lazzaro explores the gendering of sixteenth-century sculptural personifications of Florence in relation to gendered Renaissance conceptions of the city itself. At the height of its power, Lazzaro shows, Florence was presented very differently both from the dying or deceased Rome of the fourteenth to early sixteenth century (Gessert, Chapter 3) and from the armed figure of the goddess Roma in ancient Roman art, even if some aspects of the imagery, including the convention of representing cities in bodily form, bore Roman origins. In Chapter 10, "Figuring Florence: Gendered Bodies in Sixteenth-Century Personifications and their Antique Models," Lazzaro shows how artists emphasized sexual power in female as well as male personifications of Florence. Both idealized female figures and virile male river gods, Lazzaro argues, served to characterize the city as a bountiful nurturer and impregnable military power. Artists imbued their personifications with the signature expressive torsion of Michelangelo to convey the qualities of strength and grace, as exemplified by Giambologna's fountain statue Fiorenza (possibly c. 1560 or c. 1570).

In Chapter 11, “Conjugal Piety: Creusa in Barocci’s Aeneas' Flight from Troy,” Ian Verstegen addresses the role played by Creusa in Federico Barocci’s 1586 painting of Aeneas and his family leaving Troy, a lost work of which a copy by the artist survives. In Verstegen's interpretation, Barocci's painting, sent by Duke Francesco Maria II of Urbino to the Holy Roman Emperor Rudolf II, depicts Creusa accepting her divinely ordained disappearance from the 
family (as in Virgil's Aeneid 2.776-89) and thereby enabling Aeneas to fulfill his destiny as founder of Rome. In the aristocratic ambit of Francesco Maria II and Rudolf II (who claimed Trojan descent), Verstegen contends, Creusa could be read as a model for sixteenth-century noble wives: They were crucially important in bonding family lines, but their husbands sometimes needed to leave them behind to create new alliances.

Katherine M. Bentz parses the negative reactions to displays of ancient statuary in the gardens of wealthy collectors in Cinquecento Rome in Chapter 12, "Ancient Idols, Lascivious Statues, and Sixteenth-Century Viewers in Roman Gardens." Bentz identifies concerns among a minority of viewers - all elite men, most Church prelates and/or reformers — that such displays violated Christian principles by glorifying the idols of pagan gods. In the wake of the Council of Trent, Bentz observes, these critics further denounced the sensuality of the classical nudes on display. The perceived eroticism of these images in their garden settings was exacerbated by, and in turn served to strengthen, contemporary associations between gardens and female sexuality. Another cause for anxiety was the accessibility of elite gardens to foreigners, common people, and women, who might interpret the displays incorrectly. Like Simons (Chapter 8), Bentz reveals an aspect of Renaissance classical reception that was shot through with fear and repugnance, partly because of the perceived threat of titillation. Like many of the contributors, moreover, Bentz demonstrates that receptions of ancient art in the early modern era were markedly heterogeneous - and that contemporaries recognized this diversity.

\section{Thematic Threads}

Weaving these chapters together are not only their chronological and theoretical parameters but also a number of recurring themes, themselves interrelated. Many of the contributors, for 
example, find manifestations of the notion that control of the body bears on the ordering of society. The images discussed here, whether ancient, late medieval, or early modern, present human bodies managed by multiple agents: by their artists and patrons; within the narrative frame, by themselves and by any figures that watch them; and, in their reception, by their owners and audience. In all of these contexts, the gaze is a crucial force in imposing norms upon the body, a paradigm articulated by Michel Foucault. ${ }^{73}$

One site for this disciplining of the body is the hair, a subject of recent theoretical work. ${ }^{74}$ The lush, well-groomed tresses of a beautiful young woman can serve as a badge of fertility: Giambologna's hair-wringing Fiorenza, her pose derived from the ancient Venus Anadyomene image type, embodies the fecundity of Florence (Lazzaro). The long hair of witches, on the other hand, is streaming and wild, as in the Stregozzo and in Dürer's Witch riding backwards on a goat. Evoking the flying hair of raving Bacchantes/maenads and even the tangled snakes of the Medusa, the unfettered tresses of hags signify that these old women are repugnant and unnatural in their sexual desires and in their erotic hold over young men (Simons). Personifications of conquered cities, too, can have long, disheveled locks, but here the dishabille has been imposed upon the figure: The tumbling hair of the most prominent female captive in Baccio Bandinelli's relief for the monument to Giovanni dalle Bande Nere—a detail mentioned by Vasari—gives visual form to the poetic topos of conquest as sexual domination (Lazzaro). Other hairstyling

${ }^{73}$ Michel Foucault, Discipline \& Punish: The Birth of the Prison, trans. Alan Sheridan (Harmondsworth: Penguin Books, 1977).

${ }^{74}$ Roberta Milliken, Ambiguous Locks: An Iconology of Hair in Medieval Art and Literature (Jefferson, NC: McFarland, 2012); Geraldine Biddle-Perry and Sarah Cheang, eds. Hair: Styling, Culture and Fashion (Oxford: Berg, 2008); Elizabeth Bartman, "Hair and the Artifice of Roman Female Adornment," American Journal of Archaeology 105 (2001), 1-25. A fundamental early study is C. R. Hallpike, "Social Hair," Man 4 (1969), 256-64. Some of these themes will be presented in the forthcoming October-December 2015 exhibition Hair in the Classical World, Bellarmine Museum of Art, Fairfield University. 
conventions convey the moral rectitude of potentially problematic female figures. Signorelli's Veturia makes the adlocutio gesture of ancient male orators and possesses a level of persuasive power generally associated in early modern thought with men rather than women, but she is veiled as a properly modest Roman matron (Leone). In the bed valances depicting the myth of Philomela, Queen Procne and her companions are bona fide Bacchantes with thyrsi, but their hair is meticulously pinned up; together with their impeccably elegant attire, the figures' well-tended, of-the-moment coiffures suggest that the mission to liberate Philomela is worthy of the most noble of women, even contemporary ones (Joyce).

Clothing is, of course, another powerful means of expressing conformance with or departure from societal gender roles. Cross-dressing a figure in garb conventionally associated with the opposite sex does not always cast him or her in a negative light, however. Giotto's Fortitude at the Arena Chapel is a woman with breastplate, lion skin, mace, and battleworn fullbody shield who nonetheless embodies a Virtue. In Edwards's reading, furthermore, this figure represents the absolution of Hercules by Omphale and of Enrico Scrovegni by the Virgin Mary. The ancient fragment of a statue group in Rome known as the Pasquino, to which thousands of Latin verses satirizing contemporary politics and pedagogy were affixed from the end of the fifteenth century onward, could be costumed on the feast day of St. Mark as either a male or a female pagan deity or personification to invite the composition of poetry on related themes (Smith).

The reception of ancient art requires any culture to engage with the use of nudity in signifying the individual's relationship to gendered social ideals. ${ }^{75}$ For Kenneth Clark, the

\footnotetext{
${ }^{75}$ Michael Squire, The Art of the Body: Antiquity and Its Legacy (London: Tauris, 2011), esp. 69-153.
} 
embrace of the beautiful classical nude is a defining aspect of the Renaissance. ${ }^{76}$ This volume demonstrates, though, that antique nude statues, and nude figures adapted from ancient imagery and literature in early modern art, interacted in complex and diverse ways with contemporary gender norms. Certainly, the alluring nudity of Venus, and of some other female mythological figures and personifications, could serve to glorify the patriarchally defined roles of women as erotic objects of the male gaze and, in some cases, as the muses of male artists and authors. The reclining nude goddess in Lorenzo Lotto's Venus and Cupid likely plays both parts (Oettinger). On the other hand, the nude Pasiphaë copulating with the bull on one of the maiolica dishes from Mantua is not classically idealized: She has the pronounced musculature of a man, a visual cue that her act is unnatural. When the plate was viewed at banquets, Federico II Gonzaga and the men of his court may well have enjoyed a laugh at Pasiphaë's expense, but female guests may have appreciated Pasiphaë's sexual agency (Maurer). The naked bodies of old witches, with their sagging, dried-up breasts, represent repellent inversions of the classical ideal, but they nevertheless form part of the vocabulary of "Renaissance" art, which, pace Clark, does not merely elevate the beautiful (Simons). Not all witches are hideous, either: Dosso Dossi's Circe is a highly idealized nude with long, soft, goldspun tresses. She offers viewers a metaphor, Simons argues, for the enchanting nature of artistry.

Early modern artists studying ancient male nude statues perceived a range of physical types, from the powerful to the feminized—-sometimes even in the same work of art. As Smith shows, sixteenth-century drawings of the Belvedere Torso demonstrate the fluidity of gender in receptions of this famous sculptural fragment. In the pen-and-ink sketch by Amico Aspertini that appears on this volume's cover, for example, the angled view of the Torso conceals its genitalia

\footnotetext{
${ }^{76}$ Kenneth Clark, The Nude: A Study in Ideal Form (New York: Pantheon, 1956).
} 
and lends a feminine curve to the breast. Sodoma's adaptation of this model for the figure of Niccolò di Tuldo, Smith contends, allows the beholder to map onto the decapitated body the full range of male and female metaphors employed by St. Catherine to characterize Niccolò in her letter. This combination of male and female physical qualities also permits the viewer to reconstruct the figure in the mind's eye with Catherine's own head, a relic housed in the same space, and thus to recast Niccolò's death as the saint's wished-for martyrdom.

Renaissance audiences also received some classical nude statues as fully intersexual, including not only sculptures originally carved as hermaphrodites but also two ancient Apollos in the Sassi collection. The display of the Apollo statues in the Sassi palace courtyard and their repeated copying by artists, as well Lorenzo Ghiberti's effusive praise of a hermaphroditic statue, testify to the high status of these images (Gessert). Both Smith and Gessert thus support and expand upon Leonard Barkan's thesis that early modern audiences did not automatically perceive the gender of ancient sculptures in fixed, binary terms. ${ }^{77}$

For some sixteenth-century viewers, however, any nude antique statuary was problematic. A minority of conservative clerics and other elite male critics objected to ancient works of art not only because of their believed connection to pagan idolatry but also because they could possess great erotic power (Bentz). The display of nude statues in gardens was especially troublesome, Bentz notes, since the lush natural setting, gendered female in Renaissance thought, amplified their sensuousness. The "Renaissance" admiration of the classical nude was not universal.

Pose and gesture are also crucial to gendered expectations of, and performances by, the body. In Barocci's Aeneas' Flight from Troy, Creusa's lowered head, deep bow, and outstretched

${ }^{77}$ Barkan, Unearthing the Past, 164-84. 
hand convey the same resignation as the downcast gaze and open hand of Barocci's dutiful Annunciate Virgin (Verstegen). Like Mary expressing her submission to the will of God, Creusa signals her acceptance of the destiny that will propel Aeneas and his line to greatness without her. She thus embodies the ideal of a pious wife in an early modern dynastic marriage, Verstegen contends. Alternatively, pose can mark a figure as a negative exemplar: The figure of Pasiphaë entering the cow costume in Giulio Romano's fresco assumes the ancient bent-knee pose of the male hero wrangling a beast. The appropriation of this iconography characterizes Pasiphaë as transgressing the natural order, although the painting, like the maiolica dishes probably used in the same room of the Palazzo del Te, may have elicited differing reactions between its male and female viewers (Maurer). The oratorical gesture of Veturia in Signorelli's fresco is the force that controls the encounter of the Roman matrons with Coriolanus and his armed companions. Because Veturia's act of persuasion put her at odds with contemporary ideals of female passivity, her status as model of motherly virtue was not always secure in the receiving literature, but Vittoria Piccolomini and Aurelia Petrucci may well have viewed this speaking figure positively (Leone). Other poses identified as masculine could be acceptable and even desirable in female personifications, as Michelangelo's Night in the New Sacristy of San Lorenzo assured later Florentine sculptors. The Florence of Giambologna's Florence Triumphant over Pisa, a classical nude with artfully styled hair, twists her body to subjugate the kneeling male Pisa, recasting this conquest as an amorous one, but nonetheless glorifying the military might of the victorious city (Lazzaro).

Another recurring theme in these essays is the violation of the body and its meanings within classical reception in late medieval and early modern visual contexts. The act today known as rape, namely the forcing of an unwilling partner into sexual intercourse, is one such 
violation, although it was not always viewed as such in the periods under discussion here. ${ }^{78}$ As Diane Wolfthal points out, fourteenth- to seventeenth-century images that depict ancient gods or heroes committing sexual violence often employ formal and narrative means to lionize the perpetrators as "heroic," or at least to downplay the negative impact of their acts. Some modern art historians, she observes, perpetuate the notion of the "heroic" rape by using terms for these subjects that do not connote sexual violence, such as "abduction," and by lauding the genius of the (male) artist. ${ }^{79}$ Euphemisms for rape occur in the present volume as well, but in the context of deconstructing images that celebrate men's metaphorical or actual sexual subjugations of women. The triumphal relief by Baccio Bandinelli of Giovanni dalle Bande Nere receiving prisoners, Lazzaro shows, is this type of scene: It assimilates victory to rape not only through the disarray of the main female captive's hair, as noted above, but also through the pose of the soldier who restrains her, jutting a knee between her legs. Here, as in "heroic" scenes with explicitly mythological or legendary subject matter, the borrowings from antiquity—in this case, among other things, the dependence on Roman mythological rape scenes, such as Hades sweeping Persephone onto his chariot—help to normalize the equation of glorious victory with unwanted sex (Lazzaro).

The case studies by Murray/Simone and Joyce of two different mythological rapes in the fourteenth-century Rouen and Paris Arsenal manuscripts of the Ovide moralisé together illustrate how widely attitudes towards victims could vary within a single receiving context. Murray and Simone follow Rachel Jacoff in seeing two characterizations of Europa's rape by Jupiter as a bull

\footnotetext{
${ }^{78}$ On the dependence upon cultural context of definitions of sexual violence, see Mieke Bal, "Scared to death," in The Point of Theory: Practices of Cultural Analysis, ed. Bal and Inge E. Boer (New York: Continuum, 1994), 32-47: 37-8.

${ }^{79}$ Diane Wolfthal, Images of Rape: The "Heroic" Tradition and its Alternatives (Cambridge: Cambridge University Press, 1999), 7-35.
} 
in Ovid's Metamorphoses, the first looking ahead toward Europa's triumphs (Book 2), the second expressing more sympathy for the fearful girl (Book 6); in both versions, they argue, Europa occupies a space partway between the mortal and the divine. The Ovide moralisé also renders her liminal, Murray and Simone maintain, situating her as a link between paganism and Christianity. In Rouen MS 0.4 and Paris MS 5069, the pairing of the Europa miniature with images of Christ on the road to Calvary or of the Ascension emphasize the allegorical interpretation of Europa as the soul ravished by Christ. The miniatures rely on the Greek and Roman iconography of Europa riding on the bull's back, the integrity of her fully clothed body still intact. By contrast, the paintings of Philomela in the same manuscripts vividly convey the violation of her body, even though they do not show the rape: They depict Tereus approaching Philomela from behind - a sign that she is not complicit — and pulling out her tongue to slice it off. Here and in later printed book illustrations, Joyce argues, the tongue-cutting replaces the rape to underscore the savagery of Tereus' crime. Unlike the allegorizing commentary in the text, the pictorial cycles present Philomela's rape as a heinous act, and they include a scene of the sisters' righteous revenge.

Another kind of violated body, the decomposed or dismembered corpse, is a metaphor for the city of Rome in fifteenth- and sixteenth-century Italian humanistic texts, evoking the ravages effected by time on the great ancient city (Gessert). The disintegration of this body has rendered even its gender uncertain. This very ambiguity, however, excites a desire to investigate, to discover more, to complete the picture - the same kinds of desires, Gessert observes, that were directed toward ancient sculptures identified as hermaphrodites. The same analogy perhaps applies to the reception of antique statue fragments: Like the gigantei cadaveris corrupti of Rome, these sculpted bodies despoiled by time held the intriguing potential for reanimation 
through restoration, copying, adaptation, and viewing. ${ }^{80}$ Even when their sexual characteristics survive, these fragments seem to have been particularly ripe for re-gendering, as Smith's analysis of the Belvedere Torso and Sodoma's figure of Niccolò di Tuldo makes clear.

In summary, then, this collection of essays treats some of the artists, patrons, collectors, critics, and viewers of the thirteenth to sixteenth century in Europe who grappled with the manifold mass of ancient works of art, iconographic motifs, texts, and other survivals and discoveries to produce an array of often patriarchal but sometimes alternative and even subversive constructions of gender. The cultural agents under discussion here, most of them male but some of them female, drew upon the widely upheld authority of antiquity to engage with gender roles in their own society, some normative, others less so: women as sex objects, desirable brides, fecund procreators, submissive wives, persuasive mothers, grotesque witches, beautiful witches, inspiring muses, sexual aggressors, rape victims, saints, savers of men's souls, brides of Christ; men as heads of state, heads of families, good husbands, bad husbands, victors in battle, sexual conquerors, rapists, sinners needing expiation, brides of Christ; those of dual sexuality as objects of fascination; and many more. The reception of antiquity in late medieval and early modern art, these essays reveal, interacted in a myriad of ways with the understandings and lived experiences of gender in these periods.

\footnotetext{
${ }^{80}$ Barkan, Unearthing the Past, 1999, 119-207, but without connecting the reception of fragments to the topos of Rome as corpse. Linda Nochlin, The Body in Pieces: The Fragment as a Metaphor of Modernity (New York: Thames and Hudson, 1992), sees kinship between dismembered bodies and ancient sculptural fragments, although her focus is the French Revolution to the postmodern era.
} 
Bibliography

Ainsworth, Maryan W., ed. Man, Myth and Sensual Pleasures: Jan Gossart's Renaissance. New Haven: Yale University Press, 2010.

Ajmar, Marta. "Exemplary Women in Renaissance Italy: Ambivalent Models of Behavior?” In Women in Italian Renaissance Culture and Society, edited by Letizia Panizza, 244-64. Oxford: University of Oxford European Humanities Research Center, 2000.

American Historical Review Forum. "The Persistence of the Renaissance." American Historical Review 103, no. 1 (1998): 50-122.

Bal, Mieke. "Scared to Death." In The Point of Theory: Practices of Cultural Analysis, edited by Mieke Bal and Inge E. Boer, 32-47. New York: Continuum, 1994.

Barkan, Leonard. Unearthing the Past: Archaeology and Aesthetics in the Making of Renaissance Culture. New Haven: Yale University Press, 1999.

Bartman, Elizabeth. "Hair and the Artifice of Roman Female Adornment." American Journal of Archaeology 105 (2001): 1-25.

Baskins, Cristelle. Cassone Painting, Humanism and Gender in Early Modern Italy. Cambridge, UK: Cambridge University Press, 1998.

Bennett, Judith. History Matters: Patriarchy and the Challenge of Feminism. Philadelphia: University of Pennsylvania Press, 2006.

Biddle-Perry, Geraldine, and Sarah Cheang, eds. Hair: Styling, Culture and Fashion. Oxford: Berg, 2008.

Bleeke, Marian. "Feminist Approaches to Medieval Visual Culture: An Introduction.” Medieval Feminist Forum 22 no. 2 (2008): 49-52.

Bober, Phyllis Pray, and Ruth O. Rubinstein. Renaissance Artists and Antique Sculpture: A Handbook of Sources. Oxford: Oxford University Press, 1986 (rev. ed. 2010).

Brinkmann, Vincenz ed. Zurück zur Klassik: Ein neuer Blick auf das alte Griechenland. Munich: Hirmer Verlag, 2013.

Broude, Norma, and Mary D. Garrard. "Introduction: Reclaiming Female Agency." In Reclaiming Female Agency: Feminist Art After Postmodernism, edited by Norma Broude and Mary D. Garrard, 1-25. Berkeley: University of California Press, 2005. eds. The Expanding Discourse: Feminism and Art History. Boulder, CO: Westview

Press, 1992. 
Brown, Patricia Fortini. Venice and Antiquity: The Venetian Sense of the Past. New Haven: Yale University Press, 1997.

Bull, Malcolm. The Mirror of the Gods: Classical Mythology in Renaissance Art. Oxford: Oxford University Press, 2005.

Burioni, Matteo. "Vasari's Rinascita: History, Anthropology, or Art Criticism?," in, Renaissance? Perceptions of Continuity and Discontinuity in Europe, c. 1300- c.1550, edited by Alexander Lee and Pit Péporté, 115-28. Leiden: Brill, 2008.

Burke, Jill, ed. Rethinking the High Renaissance: The Culture of the Visual Arts in Early Sixteenth-Century Rome. Burlington: Ashgate, 2012.

Camille, Michael. The Gothic Idol: Ideology and Image-making in Medieval Art. Cambridge, UK: Cambridge University Press, 1989.

Campbell, Stephen J. The Cabinet of Eros: Renaissance Mythological Painting and the Studiolo of Isabella d'Este. New Haven: Yale University Press, 2004.

Chance, Jane. Medieval Mythography. 2 vols. Gainesville, FL: University Press of Florida, 1994 and 1995.

Clark, Kenneth. The Nude: A Study in Ideal Form. New York: Pantheon, 1956.

Cunnally, John. Images of the Illustrious: The Numismatic Presence in the Renaissance. Princeton: Princeton University Press, 1999.

Dressler, Rachel. "Continuing the Discourse: Feminist Scholarship and the Study of Medieval Visual Culture." Medieval Feminist Forum 43 no. 1 (2007): 15-34.

Dubrow, Heather, and Frances E. Dolan. "The Term 'Early Modern."' Publications of the Modern Language Society of America 109 no. 5 (1994): 1025-7.

Favaretto, Irene. Arte antica e cultura antiquaria nelle collezione venete al tempo della Serenissima. Rome: L'Erma di Bretschneider, 2002.

Ferguson, Margaret W., Maureen Quilligan, and Nancy J. Vickers. Rewriting the Renaissance: The Discourses of Sexual Difference in Early Modern Europe. Chicago: University of Chicago Press, 1986.

Foucault, Michel. Discipline \& Punish: The Birth of the Prison, translated by Alan Sheridan. Harmondsworth: Penguin Books, 1977.

Freedman, Luba. Classical Myths in Italian Renaissance Painting. Cambridge: Cambridge University Press, 2011. 
Press, 2003.

The Revival of the Olympian Gods in Renaissance Art. Cambridge: Cambridge University

Garrard, Mary D. Brunelleschi's Egg: Nature, Art, and Gender in Renaissance Italy. Berkeley: University of California Press, 2010.

Godwin, Joscelyn. The Pagan Dream of the Renaissance. Boston: Red Wheel/Weiser, 2005.

Goffen, Rona. Titian’s Women. New Haven: Yale University Press, 1997.

Goldhill, Simon. "Cultural History and Aesthetics: Why Kant is No Place to Start Reception Studies.” In Theorising Performance: Greek Drama, Cultural History and Critics' Practice, edited by Edith Hall and S. Harrop, 56-70. London: Duckworth, 2010.

Goldstone, Jack A. "The Problem of the 'Early Modern' World." Journal of the Economic and Social History of the Orient 41 no.3 (1998): 249-84.

Gombrich, E.H. Norm and Form: Studies in the Art of the Renaissance. London: Phaidon Press, 1966.

Grafton, Anthony, Glenn W. Most, and Salvatore Settis, eds. The Classical Tradition. Cambridge, MA: Harvard University Press, 2010.

Greenhalgh, Michael. The Survival of Roman Antiquities in the Middle Ages. London: Duckworth, 1989.

Hall, Edith. "Putting the Class into Classical Reception." In Hardwick and Stray, Companion to Classical Receptions, 386-97.

Hallpike, C. R. “Social Hair.” Man 4 (1969): 256-64.

Hamburger, Jeffrey. Nuns as Artist: The Visual Culture of a Medieval Convent. Berkeley: University of California Press, 1997.

The Rothschild Canticles: Art and Mysticism in Flanders and the Rhineland circa 1300. New Haven: Yale University Press.

Hardwick, Lorna. “Editorial.” Classical Receptions Journal 2 (2010): 1-3.

Reception Studies. Greece and Rome New Surveys in the Classics 33. Oxford: Oxford University Press, 2003. and Christopher Stray, eds. A Companion to Classical Receptions. Blackwell Companions to the Ancient World. Malden, MA: Blackwell, 2011. 
Haskell, Francis, and Nicholas Penny. Taste and the Antique: The Lure of Classical Sculpture 1500-1900. New Haven and London: Yale University Press, 1981.

Hurlburt, Holly. “A Renaissance for Renaissance Women?” Journal of Women's History 19, no. 2 (2007): 193-201.

Jauss, Hans Robert. Toward an Aesthetic of Reception. Translated by Timothy Bahti. Minneapolis: University of Minnesota Press, 1982.

Johnson, Geraldine A., and Sara F. Matthews Grieco, eds. Picturing Women in Renaissance and Baroque Italy. New York: Cambridge University Press, 1997.

Kampen, Natalie Boymel. “On Writing Histories of Roman Art.” Art Bulletin 85 (2003): 373-83.

Kelly, Joan. "Did Women Have a Renaissance?" In Women, History and Theory: The Essays of Joan Kelly, 19-51. Chicago: University of Chicago Press, 1984. Reprinted (writing as Joan Kelly-Gradol) from Becoming Visible: Women in European History, edited by Renate Bridenthal and Claudia Koonz, 137-64. Boston, MA: Houghton Mifflin, 1977.

Kilinski, Karl. Greek Myth and Western Art: The Presence of the Past. New York: Cambridge University Press, 2013

Klapisch-Zuber, Christiane. Women, Family, and Ritual in the Renaissance. Translated by Lydia G. Cochrane. Chicago: Chicago University Press, 1985.

Krzysztof, Pomian. Collectors and Curiosities: Paris and Venice, 1500-1800. Translated by Elizabeth Wiles-Porter. Cambridge, MA: Polity Press, 1990.

Kurtz, Donna ed. Reception of Classical Art: An Introduction, Studies in Classical Archaeology, vol. 3. British Archaeological Reports, International Series 1295. Oxford: Archaeopress, 2004.

Lazzaro, Claudia. "The Visual Language of Gender in Sixteenth-Century Garden Sculpture." In Migiel and Schiesari, Refiguring Women, 71-113. Reprinted with revisions as "Gendered Nature and Its Representation in Sixteenth-Century Garden Sculpture." In Looking at Italian Renaissance Sculpture, edited by Sarah McHam, 246-73. Cambridge, UK: Cambridge University Press, 1998.

Lindquist, Sherry C.M., ed. The Meanings of Nudity in Medieval Art. Burlington, VT: Ashgate, 2012.

Martindale, Charles. "Introduction: Thinking Through Reception." In Classics and the Uses of Reception, edited by Martindale and Richard F. Thomas, 1-14. Blackwell Classical Receptions. Malden, MA: Blackwell, 2006.

. "Reception-A New Humanism? Receptivity, Pedagogy, the Transhistorical." Classical Receptions Journal 5 (2013): 169-83. 
. Redeeming the Text. Cambridge, UK: Cambridge University Press, 1993. , ed. Ovid Renewed: Ovidian Influences on Literature and Art from the Middle Ages to the Twentieth Century. Cambridge: Cambridge University Press, 1991.

McHam, Sarah Blake. Pliny and the Artistic Culture of the Italian Renaissance. New Haven: Yale University Press, 2013.

Migiel, Marilyn, and Juliana Schiesari, eds. Refiguring Woman: Perspectives on Gender and the Italian Renaissance. Ithaca: Cornell University Press, 1991.

Milliken, Roberta. Ambiguous Locks: An Iconology of Hair in Medieval Art and Literature. Jefferson, NC: McFarland, 2012.

Mulvey, Laura. "Visual Pleasure and Narrative Cinema." Screen 16 no. 3 (1975): 6-18.

Musacchio, Jacqueline Marie. The Art and Ritual of Childbirth in Renaissance Italy. New Haven: Yale University Press, 1999.

Nagel, Alexander, and Christopher S. Wood. Anachronic Renaissance. New York: Zone Books, 2010.

Nochlin, Linda. The Body in Pieces: The Fragment as a Metaphor of Modernity. New York: Thames and Hudson, 1992.

. “Why Have There Been No Great Women Artists?” ARTNews 69 (1971): 22-39, 67-71.

Oakshott, Walter. Classical Inspiration in Medieval Art. New York: Frederick A. Praeger, 1960.

Panofsky, Erwin. Renaissance and Renascences in Western Art. $2^{\text {nd }}$ ed. New York: Harper and Row, 1972.

Payne, Alina, Ann Kuttner, and Rebekah Schmicks, eds. Antiquity and its Interpreters. London and New York: Cambridge University Press, 2012.

Pollack, Griselda. Old Mistresses: Women, Art, and Ideology. London: Routledge and Kegan Paul, 1981.

Porter, James I. "Reception Studies: Future Prospects.” In Hardwick and Stray, Companion to Classical Receptions, 469-81.

Poska, Allyson M., Jane Couchman, and Katherine A. McIver, eds. The Ashgate Research Companion to Women and Gender in Early Modern Europe. Farnham, UK: Ashgate, 2013. 
Ramelli, Ilaria. "Ancient Allegory and its Reception through the Ages." International Journal of Classical Reception 18 no. 4 (2011): 569-78.

Randolph, Adrian W. B. Engaging Symbols: Gender, Politics, and Public Art in FifteenthCentury Florence. New Haven: Yale University Press, 2002.

Reid, Jane Davidson, ed. The Oxford Guide to Classical Mythology in the Arts, 1300-1990s. 2 vols. New York: Oxford, 1993.

Reiss, Sheryl E., and David G. Wilkins, eds. Beyond Isabella: Secular Women. Patrons of Art in Renaissance Italy. Kirksville, MO: Truman State University Press.

Saslow, James. Ganymede in the Renaissance: Homosexuality in Art and Society. New Haven and London: Yale, University Press, 1986.,

Stephanie Schrader, "Gossart's Mythological Nudes and the Shaping of Philip of Burgundy's Erotic Identity." In Man, Myth and Sensual Pleasures: Jan Gossart's Renaissance, edited by Maryan W. Ainsworth, 57-67. New York: Metropolitan Museum of Art, 2010.

Settis, Salvatore. Future of the Classical World. Translated by Alan Cameron. Cambridge, MA: Polity, 2006.

Seznec, Jean. The Survival of the Pagan Gods: The Mythological Tradition and Its Place in Renaissance Humanism and Art. Translated by Barbara F. Sessions. Princeton: Princeton University Press, 1953.

Shepard, Alexandra, and Garthine Walker. "Gender, Change and Periodisation." Gender and History 20 no.3 (2008): 453-62.

Simons, Patricia. "Hercules in Italian Renaissance Art: Masculine Labour and Homoerotic Libido," Art History 31 (2008): 632-64.

_ . "Lesbian (In)Visibility in Italian Renaissance Culture: Diana and Other Cases of Donna con Donna," Journal of Homosexuality 27, no. 1-2 (1994): 81-122.

Squire, Michael. The Art of the Body: Antiquity and Its Legacy. London: Tauris, 2011.

Survival of the Gods: Classical Mythology in Medieval Art. Exhibition catalogue. Providence: Brown University Bell Gallery, 1987.

Vasari, Giorgio. "Proemio delle Vite." In Le Vite de' più eccellenti pittori, scultori, e architettori da Cimabue insino a' tempi nostri. Florence: Giunti, 1568.'

Verstegen, Ian. "Vasari's Progressive (But Non-Historicist) Renaissance." Journal of Art Historiography 5 (2011): 1-19. 
Weiss, Roberto. The Renaissance Discovery of Classical Antiquity. New York: Humanities Press, 1969; $2^{\text {nd }}$ ed. 1988.

Wiesner-Hanks, Merry E. "Do Women Need the Renaissance?” Gender and History 20 no.3 (2008): 539-57.

.Women and Gender in Early Modern Europe. $3^{\text {rd }}$ ed. New Approaches to European History. New York: Cambridge University Press, 2008.

Wolfthal, Diane. Images of Rape: The "Heroic" Tradition and its Alternatives. Cambridge: Cambridge University Press, 1999.

Wood, Christopher S. “Art History's Normative Renaissance.” In The Italian Renaissance in the Twentieth Century, edited by Allen J. Grieco, Michael Rocke, and Fiorella Gioffredi Superbi, 65-92. Florence: Olschki, 2002. 
